\title{
Epistemik Merakın Eğitimdeki Rolü
}

\author{
Tuğçe YAZICI \\ Çanakkale Onsekiz Mart Üniveristesi, Eğitim Bilimleri Enstitüsü \\ yazicituce@windowslive.com \\ ORCID: 0000-0002-8523-8362 \\ Osman Y1lmaz KARTAL \\ Çanakkale Onsekiz Mart Üniversitesi, Eğitim Bilimleri Bölümü \\ oykarta179@yahoo.com \\ ORCID: 0000-0003-2922-0069
}

Derleme Makalesi

DOI: $10.31592 /$ aeusbed.738875

Geliş Tarihi: 17.05.2020

Revize Tarihi: 14.07.2020

Kabul Tarihi: 16.07.2020

\section{Atıf Bilgisi}

Yazıc1, T. ve Kartal, O. Y. (2020). Epistemik merakın eğitimdeki rolü. Ahi Evran Üniversitesi Sosyal Bilimler Enstitüsü Dergisi, 6(2), 570-589.

\section{ÖZ}

Öğrenenin öğrenme isteği, bilinçli veya bilinçsiz bir şekilde gerçekleşebilmektedir. Bu süreçte öğrenenin özellikle belli bir içeriğe yoğunlaşarak öğrenme çabasına girmesi ve öğrenme çabasının arkasındaki nedenlerin alan yazınında farklı bakış açılarla incelendiği anlaşılmaktadır. Psikolojik çerçevede öğrenenin öğrenme çabası merak olarak incelenmiştir ve meraka yönelik çeşitli tanımlamalarla birlikte birtakım teoriler öne sürülmüştür. $\mathrm{Bu}$ çalışma, epistemik merakın öğrenme açısından kavramsal ve teorik arka planının öğretme ve öğrenme süreçleri açısından açıklamayı amaçlamaktadır. $\mathrm{Bu}$ amaç doğrultusunda, epistemik merak konusunda gerçekleştirilecek bilimsel araştırmalar ve eğitim programı geliştirme çalışmaları için araştırmacılara, uzmanlara ve uygulayıcılara eleştirel bir teorik çerçeve sunmaktadır. Ayrıca, epistemik merakın öğrenme ve öğretme süreçlerine ne gibi katkılarının olabileceğini sunma açısından çalışmanın önemli olduğu düşünülmektedir. Sonuç olarak, epistemik merak, insanın bilişsel yapısı ve kişilik faktörleriyle birlikte öğrenme ve öğretme sürecine birçok açıdan bağlantılı olduğu anlaşılmaktadır. Ayrıca, epistemik merakın öğrenme sürecine bağlı değișkenlerle arabulucu bir rol üstlendiği ve öğrenme- öğretme sürecini kapsayan bir yapı haline geldiği anlaşılmaktadır. Epistemik merakın öğrenme sürecindeki rolüne aracılık eden değișkenlerin neler olabileceğinin, gerçekleştirilecek araştırmalarla, sorgulanması önerilmektedir.

Anahtar Kelimeler: Merak, epistemik merak, öğrenme ve öğretme süreci.

\section{The Role of Epistemic Curiosity in Education}

\begin{abstract}
The learning desire of the learner can be realized consciously or unconsciously. In this process, it is understood that the learner's efforts to learn especially by concentrating on a certain content and the reasons behind the learning effort are examined from different perspectives in the literature. In the psychological framework, the learning effort of the learner has been investigated as curiosity and some theories have been put forward along with various definitions for curiosity. This study aims to explain the conceptual and theoretical background of epistemic curiosity in terms of teaching and learning processes. For this purpose, it provides a critical theoretical framework to researchers, experts and practitioners for scientific research and curriculum development studies on epistemic curiosity. In addition, it is thought to be important to present what kind of contribution epistemic curiosity can contribute to learning and teaching processes. As a result, it is understood that epistemic curiosity is related to human cognitive structure and personality factors as well as learning and teaching process in many aspects. Also, it is understood that epistemic curiosity plays a mediator role with the variables related to the learning process and has become a structure that covers the learningteaching process. It is suggested that the variables that mediate the role of epistemic curiosity in the learning process can be questioned through the researches to be conducted.
\end{abstract}

Keywords: Curiosity, epistemic curiosity, learning and teaching process.

\section{Giriş}

Evrende bilinmeyen veya fark edilmemiş bilgileri keşfetme ve öğrenme çabası, insanoğlunun sahip olduğu doğal bir özelliktir. Ancak, çevresindeki uyaranlar aracılığıyla aynı anda birçok bilgiyi fark eden öğrenenin, belirli bir bilgiye neden yöneldiği ve o bilgiyi neden öğrenmeyi tercih ettiği, antik çağdan bu yana sorgulanan bir konudur. İnsanların bilgi çağında elektronik veya elektronik olmayan her türlü araç vasıtasıyla istediği bilgiye kolayca ulaşabildiği göz önünde bulundurulduğunda, 
öğrenenin belirli bir bilgi için özel olarak öğrenme çabasına girmesi, sosyal bilimlerde/eğitim bilimlerinde inceleme konusu olmaya devam etmektedir.

Öğrenmeye yönelik gerçekleştirilen psikolojik çözümlemeler incelendiğinde, öğrenmenin, öğrenendeki davranış değişimi ve öğrenenin içsel kapasitesinde meydana gelen bir değişim olması söz konusudur (Dilmaç ve Karababa, 2016). Bu değişim, öğrenenin geçirdiği yaşantılar vasıtasıyla edinilmektedir ve öğrenen, mevcut potansiyelini ve kapasitesini arttırmaktadır. Ayrıca, değişim vasıtasıyla öğrenenin potansiyelinde gerçekleşen kalıcı değişiklikler, motivasyon, ilgi, merak gibi duyuşsal faktörler aracılığıyla gerçekleşmekte, bir sonraki öğrenme durumları için öğreneni hazır hale getirmektedir. Bu noktada motivasyon, öğrenenin öğrenmeye yönelik ihtiyacının ne olduğunu tespit edebilmesi, edinilecek bilgiye yönelik ilgisinin var olup olmadığı konusunda içsel bir değerlendirme yapmasına olanak sağlamaktadır. Motivasyonun kapsamına öğrenenin ilgisi, isteği, arzusu ve ihtiyacı alınmaktadır (Cüceloğlu, 2012).

Öğrenenin öğrenmeye hazır hale gelebilmesi için ilgisini özel olarak bir bilgiye, kavrama veya olguya nasıl yönlendirdiği öğrenme süreci açısından önemli bir konudur. Bu durumda ilgi, öğrenen açısından sonucunun önemli olduğu bir durum, olay veya olgudur (Dewey, 1913). İlgi aracilığıyla öğrenenin, çevredeki uyaranları duyuları aracılığıyla algılamaktadır ve kendi ilgisini çeken duruma yönelerek, o durumu incelemeye başlamaktadır. Öğrenenin karşılaştığı duruma yönelik bilgi arayışına kaynaklık etmektedir. Ayrıca aktif öğrenme yaşantısı içerisinde, öğrenen ilgilendiği kavram, konu, olay, durum veya problemlerden bir sonuç elde edene kadar bilgi arayışını sürdürmeye devam etmektedir. Bu nedenle ilginin merak kavramı ile benzer yapıya sahip olduğunu belirtmek mümkündür (Dewey, 1910; Kaya, 2016).

Dewey (1913) ve Freud (1909) açısından merak, öğrenenin keşif davranışını sergilemesini sağlamaktadır. Öğrenmenin anahtarı olarak da tanımlanan merak (Kapıkıran ve Susar Kırmızı, 2019), ayrıca geştalt kuramında temel alınan anlayışa göre de zihindeki bilgi boşluğunun fark edilmesiyle ortaya çıkan bilgi boşluğunu doldurma çabası olarak açıklanmaktadır (Loewenstein, 1994). Bu durum, merakın keşif faaliyetlerini destekleyici duyuşsal bir unsur olduğu gibi, bilişsel anlamda zihinsel farkındalı̆̆ 1 sağlayan bir yap1 olduğunu göstermektedir. Yani merak, öğrenenin öğrenme isteğini, arzusunu tetikleyen duyuşsal motivasyonel değişken olmakla, bilişsel faaliyetleri kontrol edebilen, denetleyebilen bir değişken olmak arasında gidip gelen çok boyutlu bir yapıdır. Bu nedenle meraka ilişkin yapılan açıklamalar, Berlyne (1954a, 1954b; 1960; 1966; 1978), Loewenstein (1994), Litman (2005; 2008; 2010; 2012; 2018), Litman ve Spielberger (2003), Litman ve Jimerson (2004) tarafindan incelenerek, epistemik merak olarak kavramsallaştırılmıştır.

Sosyal bilimler/eğitim bilimleri literatürü incelendiğinde, eğitim bağlamında, Türkiye'de epistemik merak kavramına yönelik yapılan çalışmalar, akademik başarı (Eren, 2009; Eren ve Coşkun, 2016) konusunda ve üniversite öğrencileri kapsamında gerçekleştirilen incelemelerle (Demirel ve Coşkun, 2009; Elmalı Özsaray, 2016; Eren, 2011; Gülten, Yaman, Deringöl ve Özsarı, 2011) sinırlıdır. Epistemik merakın, öğrenme konusunda etkililiği ve eğitim programların işlevselliği açısından önemi dikkate alındığında, epistemik merak konusunda araştırma ve incelemelerin gerçekleştirilmesi önemlidir. Bu çalışma, epistemik merakın öğrenme açısından kavramsal ve teorik arka planının öğretme ve öğrenme süreçleri açısından açıklamayı amaçlamaktadır. $\mathrm{Bu}$ amaç doğrultusunda alan yazınındaki boşluğu doldurmak, epistemik merakın öğrenme ve öğretme süreçlerine ne gibi katkılarının olabileceğini sunma açısından önemli olduğu düşünülmektedir. Bu çalışma, epistemik merak konusunda gerçekleştirilecek bilimsel araştırmalar ve eğitim programı geliştirme çalışmaları için araştırmacılara, uzmanlara ve uygulayıcılara eleştirel bir teorik çerçeve sunmaktadır.

\section{Yöntem}

Çalışmanın amacı derleme çalışması kapsamında çözümlenmektedir. Derleme çalışması, çalışma amacı ile ilgili literatürü (alanyazını) inceleme, değerlendirme ve sentezleme sürecidir. Ayrıca, derleme çalışmasıyla, çalışma konusu ile ilgili literatürdeki eğilimlerin betimlenmesi, araştırma açığının tanımlanması ve araştırmacılara öneriler sunulması sağlanır (Palmatier, Houston ve 
Hulland, 2018). Bu kapsamda, araştırmacılar çalışma konusu ile ilgili literatürdeki temel kaynaklara ulaşarak, eleştirel bir bakış açısı ile konuyu farklı boyutları ile ele almaktadırlar. Çalışma, derleme çalışması desenlemelerinden literatür inceleme desenlemesi ile gerçekleştirilmiştir. Bu kapsamda, etik kurul raporuna gerek bulunmamaktadır. Araştırmacılar, derleme çalışması kapsamında dikkate alınması gereken bilimsel araştırma ve yayın etiği ilkelerine azami özen göstermişlerdir.

\section{Merak’a Yönelik Kavramsal Bir Analiz}

Türk Dil Kurumu (tdk.gov.tr, 2019) merak kavramın1, bir "istek duygusu” olarak tanımlamıştır. Burada öğrenenin bir olguyu, nesneyi veya bilgiyi öğrenebilmek ve tüm bunları edinebilmesi için duymuş olduğu arzu durumu söz konusudur. Bu arzu, genel ve basit bir mantıkla istek duygusu olarak nitelendirilse de felsefi ve bilimsel bir bakış açısıyla irdelendiğinde duyguları da içerisinde barındıran çok boyutlu bir yapı olduğu, bu yapının öğrenme sürecini şekillendirebildiği anlaşılmaktadır.

Felsefede merak kavramına yaklaşımlar farklılaşmaktadır. Platon açısından merakın, gerçek anlamda bilme motivasyonu veya bilgi edinme isteği, tutkulu bir hareket, iştahla bağlantıll olduğu anlaşılmaktadır (Loewenstein, 1994; Mcleod, 2011). Platon'un ifade ettiği iştah, bilgiyi edinmek için derin ve kalıcı bilgiyle sonuçlanan merakı ve öğrenme döngüsünü meydana getirmektedir (Mcleod, 2011). Kant'a (Akt. Piper, 2011) göre yeryüzündeki nesne ile insanın o nesne hakkındaki yorumunun uyumlu olması amaçlamaktadır. Bu durumda merak, insanın nesneye ilişkin yorumları aracılığıyla meydana gelen birtakım öngörüler ile sorgulamaya teşvik ederek, kişinin memnuniyet duymasını sağlamaktadır (Kant, 1790; Akt. Piper, 2011). Yani buradaki öğrenme döngüsü, bireyin zihninde neyi bildiği veya neleri bilebileceği hakkında yargıda bulunabilmesi üzerine temellendirilmektedir ve merak olarak nitelendirilen memnuniyet, bireyin geçirdiği yaşantı sonucu edindiği deneyimler ile algıladığı bilgilerin mantık aracılığıyla zihinde yorumlanmasına neden olmaktadır. Ayrıca merak, algılar yoluyla edinilen bilgilerin mantık tarafından değerlendirilmesini sağlamaktadır.

Aristoteles açısından merak, evrensel olan bilme arzusudur ve öğrenenin kendi iyiliği için bilgiyi aramasıdır (Ross 1975; Akt. Reiro, Petrosko, Wiswell ve Thongsukmag, 2006). Merak, insan doğasıyla ilgili olduğu gerekçesiyle Skolastik felsefecilerin, Aquinas'ın "doğal doyumsuzluk" (Cho, 2008), Bacon'da "organik büyüme" (Blumenberg 1985; Akt. Cho, 2008), Cicero'da "öğrenmeye yönelik tutku" (Cicero, 1914; Akt. Loewenstein, 1994), Augustine'de (1943) merak, bilgiye ulaşmak için diğer kişiler tarafindan nedeni anlaşılamayan istekli olma durumudur. Merak öğreneni çevreden edindiği tüm bilgileri zihninde yapılandırabilmesi ve yeni bilgiler edinebilmesi amacıyla harekete geçirmektedir.

Ancak yapılan tanımlar dışında dikkat çeken husus, meraka karşı yapılan tartışmaların (Cicero'dan Augustin'e kadar) ahlaki boyutu kapsamasıdır (Cho, 2008). Örneğin toplum içerisinde misafir olarak gidilen bir yerdeki çekmeceleri karıştırmak, sınıf ortamında öğretmenden izinsiz dolabını açmak, kapıdan konuşmaları dinlemek veya insanlar hakkında özel bilgileri soruşturmak toplumda pek hoş karşılanmayan durumlardan bazılarıdır. Dolayısıyla merak kavramı olumlu yönlerine dair açıklamalarla birlikte 1950'li yıllardan önce meraklı olarak nitelendirilen insanlar yeni bir şeyi bilmek uğruna heves veya aç gözlülük (eagerness or greed) sergilemesi (Slater, 2009) nedeniyle merakın olumsuz bir kavram olarak nitelendirilmesi söz konusudur (Edelman, 1997). Sonuçta merak zihin ve mantığın işleyişine katkı sağlamasıyla birlikte öğreneni olumsuz davranışlar sergilemeye sevk etmektedir.

Felsefenin bakış açısının yanında, meraka yönelik gerçekleştirilen bilimsel çözümlemeler ile kavramsal arka planına yönelik işlevsel tanımlamalar ortaya çıkmıştır. Sosyal bilimler açısından merak kavramı, öğrenenin bilgi arayışı için yoğun zaman ayırmaya kaynaklık eden tahrik duygusu olmanın yanında, keşif davranışlarına motivasyon sağlayan, yeni bilgi ve alışılmamış duyuşsal deneyimi edinme arzusu olarak açıklanmaktadır (Berlyne, 1954a; Litman ve Jimerson, 2004; Litman ve Spielberger, 2003; Loewenstein, 1994). Bu durum, öğrenenin yeni karşılaştı̆̆ı durumları zihninde 
anlamlandırabilmesini sağlayan istek ve arzu gibi duyguların öğrenim zamanını planlaması üzerinde etkin bir rol oynadığını göstermektedir. Yani öğrenenin bir bilgiyi edinebilmek için ayıracağı zaman, o bilgiyi edinmeye yönelik istek, arzu ve ilgisinin derecesine bağlıdır.

Öğrenme sürecinde öğrenenin karşılaştığı uyaranların dikkat çekicilik derecesi, öğrenenin ilgisini hangi uyarana yönlendireceğini belirleyebilmektedir. Bu aşamada merak, birtakım uyaranlar tarafından yönlendirilmiş bir ilgi hali olarak nitelendirilmektedir (Day, 1982). Merakın olumlu ya da olumsuz olarak farklı türlerde tepkilere kaynaklık edebildiğini göstermektedir. Öğrenenin yaşadığı zevk veren bir ilgi duygusu ile belli bir düzeyde öğrenene rahatsılılı veren belirsizlik duygusunun görüldüğü iki farklı tepki türünü içerisinde barındırmaktadır (Litman ve Jimerson; 2004). Dolayısıyla merakın, uyaranların niteliğine bağlı olarak öğrenenin göstereceği tepkiler üzerinde belirleyici bir unsur olduğu anlaşılmıştır. Ancak çevresel uyarıcıların öğrenen tarafından farklı biçimlerde anlamlandırılması sonucu algının meydana gelebildiği varsayıldığında, merakın farklı bir biçimde ifade edilmesi söz konusudur. Merak, bilgi edinimi sonucu zihinde meydana gelen algısal çatışma ve algısal boşluğun devamlılığının sürdürüldüğü durumlarda, algısal boşlukları ortadan kaldırmada yararlanılan duyuşsal-motivasyonel yapı içerisindedir (Kashdan ve Fincham, 2002). Aktif öğrenme süreci içerisinde bilişsel yapılarda meydana gelen bilgi boşluklarını tamamlayabilmek, yanlış veya eksik edinilen bilgilerin neden olduğu rahatsızlıkları tespit edebilmek ve ortadan kaldırabilmek için merak, zihinsel bir denetim mekanizması rolü üstlenmektedir. Öğrenen tarafından verilecek tepkileri şekillendiren bir yapıya bürünmektedir.

\section{Merak Teorileri}

Genel anlamda, öğrenenin bilgi arama isteği (Berlyne, 1954a) olarak ifade edilen merak, öğrenene öğrenme davranışını sergiletmesiyle birlikte öğrenme sürecine karmaşık şekilde bağlıdır. Merak öncelikle uyaran-dürtü ve motivasyon açısından incelenirken, ilerleyen dönemlerde biliş gibi kavramları bir araya getirebilen bir yapı olarak incelendiği anlaşılmaktadır. Livson'a (1967) göre merak, öğrenenin meraklı olması, öğrenenin karşılaştığı durumun merak uyandırıcı olması ve öğrenenle etkileşim halinde olan veya bireysel farklılıklarına bağlı olan motivasyonel bir durumdur. Bu nedenle merak, dürtüsel, motivasyonel ve bilişsel- duyuşsal-motivasyonel gibi birden fazla yapının bileşimi olarak birbirinden farklı yapılarda incelenmektedir.

Öğrenenin hayati gereksinimlerini edinme konusunda harekete geçmesini sağlayan dürtü, merak açısından inceleme konusu haline gelmiştir. Dürtü teorisine göre merak, öğrenenin daha önce karşılaşmadığ 1 , karmaşık veya belirsiz uyaranlarla karşılaşmasından kaynaklanan yaşadığı rahatsızlık ve belirsizlik durumudur (Litman, 2018). Bunun örneği olarak okula başlayana kadar anne ve babasıyla zaman geçiren çocuğun okulun ilk günü kalabalık bir sınıf ortamıyla karşılaştığında bilinmezliğin vermiş olduğu tedirginlikten kaynaklanan tepkiler olabilir. Merakın dürtüler aracılığıyla meydana getirdiği diğer bir durum, uyaranlar sonucu harekete geçen dürtülerin, öğrenenin ihtiyacı olana ulaşması hususunda içsel motivasyon tarzını açıklayan davranış şekillerini sergilemesidir (Berlyne, 1978). Örnek olarak, öğrenen yaramazlık yaptı̆̆ 1 gerekçesiyle öğretmeni tarafindan teneffüse çıkması engellendiğinde açlık gibi dürtülerini gidermekten mahrum kalmaktadır. Öğrenenin dürtülerden kaynaklı meydana gelen huzursuzluk sonucu öfke gibi duyuşsal tepkiler göstermektedir. Açlığını giderebilmek için alternatif yollar arama konusunda merakı harekete geçmektedir. Böylece, ihtiyacının karşılanması sonucu, ögrenende var olan gerginlik durumunun azalmakta ve normal koşullarına erişmektedir.

Cinsellik dürtüsü üzerine de temellendirilen merak kavramı, öğrenenin cinsel meselelere yoğun ilgi gösterilmesine bağlıdır ve öğrenenin davranışlarını harekete geçiren somut itici bir güç olarak nitelendirilmektedir (Freud, 1909; Akt. Aronoff, 1962). Bu açıdan merak, temel ve yoğun dürtüler sonucu öğrenmeye yönelik isteklendirme halidir. Psikanalitik kuram çerçevesinde açıklanan bu durumda, çocuğun cinsiyet kimliğini sağlıklı bir şekilde edinebilmesi için cinsiyetler arası farklılıkları keşfetme çabasıyla birtakım sorular sormasıyla o çocuğun doğası gereği meraklı olduğuna karar verilmektedir. Diğer yandan çocuğun cinsellikle ilgili sorgulamalarda bulunmaması meraksızlık anlamına gelmektedir (Freud 1959; Akt. Cho, 2008). Yani çocuğun cinsel eğilimleri ve fizyolojik 
olarak kendi bedenini tanıma çabasından hareketle keşif davranışına yönelirse o çocuk meraklı olarak nitelendirilir.

Öğrenenin gereksinimleri sonucu harekete geçen dürtüler dışında karşılaşılan diğer bir durum, süregelen bir durum karşısında uyarılmasının devam etmesini sağlayan motivasyonel koşullardır. Optimal düzey teorisyenleri açısından merak, uyaran yoksunluğunun var olduğu bir ortamda öğrenenin bir çeşit uyaran arama çabasıyla mevcut olan uyarılma seviyesinin devamlılığına yönelik sağlanan motivasyondur (Litman, 2018). Öğrenen, öğrenme sürecinin gerçekleşmesinin devamlılı̆̆ını sağlarken aynı zamanda içsel bir çaba göstermektedir. Hedeflenen durum, öğrenenin keşif davranışının uyarılmasının arttırılması ve devamlılı̆̆ının sağlanmasıdır (Kashdan, Rose ve Fincham, 2004; Litman, 2018; Litman ve Jimerson, 2004). Yani öğrenenin olumlu veya olumsuz, çözüme ulaşabileceği veya ulaşamayacağı her türlü durumda uyarılmasını belli düzeyde tutmaktadır ve yeni uyaranların arayışı için içsel motivasyon sağlamaktadır. Örneğin bir sınıfta grup çalışmalarını yürüten öğrencilerin sınıftaki yüksek düzey gürültüye rağmen öğretmenlerinin verdiği grup çalışmasında etkinliklerinin bütün aşamalarını tamamlamaktadır. Sınıf ortamının gürültülü olması diğer arkadaşının veya incelediği öğretim materyalin içeriğini anlama konusunda öğrenenin zorluk yaşamasına neden olabilir. Ancak çalışmayı tamamlayabilmek için gereken bilgi edinimine devam edecek uyaran arayışı konusunda kendisini motive etme çabası merakı açıklamaktadır.

Motivasyonun hangi koşul ve duyuşsal durumlarda meydana geldiğinin araştırılması, merakı açıklayan bir başka durumdur. İkili işlem (Dual Process) teorisine göre, öğrenen bir yandan keşif davranışına teşvik etmek için motivasyon sağlarken diğer yandan kaygı gibi duyuşsal durumda, öğrenenin uyarılma seviyesinin azaltılması için motivasyon sağlanmaktadır (Fulcher, 2004). Bu durum merakın motivasyon üzerinde kontrol sağlayan bir unsur haline geldiğini ve öğreneni öğrenme sürecinde hem olumlu (isteklilik vb.) hem de olumsuz (kaygı, üzüntü, anksiyete vb.) duygu düzeylerini arttırdığı veya azalttığını göstermektedir. Örneğin arkeoloji bölümünde öğrenim gören bir öğrenci bilmediği, tarihi bir yapıyı keşfetmek için isteklilikten kaynaklanan yoğun bir motivasyona sahip olduğu varsayılsın. Bu öğrenci aynı zamanda bulunduğu tarihi yapıda karşılaşabileceği durumların ne olabileceği konusundaki bilinmezlik sonucunda hissettiği endişe hali öğrenenin keşif davranışını engelleyerek öğrenme ortamını terk etmesine neden olabilir. Ancak diğer yandan keşfetmeye yönelik motivasyonun, kaygı gibi olumsuz duyuşsal durumlara etki ederek, öğrenenin uyarılma düzeyini düşürebilir, keşif faaliyetinin devamlılığını sağlayabilir. Kısacası motivasyon, merakın kişilik özellikleri bağlamında incelenmesine kaynaklık etmektedir.

Spielberger'a (1966) göre kişilik ve durum teorisi olarak açılanan merak, öğrenenin kişilik özelliğindeki kaygı faktörünü kalıcı bir kişilik özelliğine bağlı, bütün sabit bireysel farklılıkların ölçülmesiyken, durum kayg1 faktörü, zaman içinde değişkenlik gösteren geçici bir durum veya öğrenenin durumunu açıklayan ölçümlerde değişkenlik gösteren yapılardır. Merak, durum ve kişilik teorisi açısından incelendiğinde durum merakı, belirli bir duruma ve bulunulan koşula yönelik öğrenenin sergilediği merakı ifade ederken; kişilik merakı, merakı deneyimlemek için genel olarak öğrenenin sahip olduğu kapasite veya eğilimi ifade etmektedir (Loewenstein, 1994). Açıkçası içinde bulunulan durum ve sahip olunan kişilik özelliği, merakı harekete geçirmekte, süreç içerisinde merakın derecesini belirleyen bir unsur haline gelmektedir.

Çağdaş öğrenme anlayışı açısından öğrenen doğası gereği araştırmaya ve incelemeye meyillidir. Zihin sürekli bilgiye yönelik tetikte olmakla birlikte, araştırmacı bir tutum sergilemektedir ve kendi düşüncesini meydana getirebilmek için malzeme arayışına yönelmektedir (Dewey, 1910). Bu nedenle merak motivasyonel ve uyaranlar açısından çok yönlü incelenmekte, fizyolojik, sosyal ve entelektüel merak boyutlarıyla açıklanmıştır. Fizyolojik merak, bir nesnenin özelliğini keşfetmesine neden olan fizyolojik bir huzursuzluk halidir. Sosyal merak, sosyal uyaranların etkisi altında gelişerek öğrenenin sosyal çevresi kanalıyla teşvik edilmesiyle keşif hareketine geçirmektedir. Entelektüel merak, nesnelerin gözlemlenmesiyle olguların bir araya gelmesiyle meydana gelen sorunların ilgiye dönüşme derecesidir (Dewey, 1910; Reiro, 2006). Aktif öğrenme sürecinde öğrenen, entelektüel düzeyini ilgileri doğrultusunda geliştirmektedir ve sosyal bir çevre olarak okul ortamının öğrenen ilgilerine göre oluşturulması, öğretmenlerin öğrenci ilgisini dikkate alması gerekmektedir (Gutek, 
2014). Bu aşamada öğrenenin ilgilerinden hareketle sahip olduğu bilgilerin niteliği sorgulanmaktadır. Merak, harekete geçirilmesiyle öğrenen tarafından bilgi eksikliğinin fark edilmesine bağlıdır ve uygun koşulların sağlanması durumunda, öğrenen için ilgi alanının kalıcı hale gelmesine neden olmaktadır (Reiro vd., 2006). Dolayısıyla uzmanların, öğretme sürecini öğrenenin kişisel ilgilerini saptayıcı ve meraklarını geliştirici etkinliklerle düzenleyerek öğrenme niteliğini geliştirmeleri gerekmektedir.

Merak kavramına yönelik yapılan açıklamalarda merakın dürtü ve motivasyon açısından olduğu gibi bilişsel- motivasyonel yapı içerisinde incelendiği anlaşılmaktadır. Öğrenme süreci içerisinde öğrenen, zihinsel algı yapısındaki uyumsuzluktan dolayı zihninde var olan birtakım bilgi boşluğuna odaklanmaktadır. Öğrenenin merak altında bir yoksunluk hissi yaşamamasına neden olmaktadır. Öğrenenin, yoksunluk hissini azaltmak veya ortadan kaldırmak için eksik bilgileri elde etmek üzere içsel motivasyon sağlaması bilgi açığı teorisi olarak nitelendirilmektedir (Loewenstein, 1994).

Bilgi açığı teorisinin temel yapısına göre, alg1 yasalarında meydana gelen uyumsuzluğun zihinde yer alan bilgi boşluklarılya ilişkilendirilmesi sonucunda merak meydana gelmektedir. Rinkevich'e (2014) göre bilgi açı̆̆ı teorisinde, öğrenenin önceden bir konu hakkındaki bilgisinde bir boşluk olduğunu veya temel olarak bir öğrenenin bilmek istediklerinin sahip olduğu mevcut bilgileri tarafından karşılanmadığının fark etmesiyle merak oluşmaktadır. Başka bir açıdan merak, bilişte fark edilen bilgi boşluklarını tamamlaması için öğreneni harekete geçiren güç haline gelmektedir (Loewenstein, 1994). Sonuç olarak merak iki farklı yapının birleşimi olarak (duyuşsal- bilişsel merak, özgül- spesifik merak ve algısal-epistemik merak) olarak açıklanmıştır.

Merak, keşif davranışına yönelik öğrenenin yaşadığı heyecan ve endişe bileşimi (duyuşsal merak) ile nesnelerin kavranmasını sağlayan yolların ve zihinde var olan bilgi boşluklarının öğrenen tarafından tespit edilmesi sonucu bilgiye ulaşmanın verdiği keyif duygusudur (bilişsel merak) (Berlyne, 1954a, 1954b, 1960; William James 1950; Akt. Reiro vd., 2006, s. 119; Malone, 1981). Bu nedenle merak kavramı, motivasyonel durumlar ile bilişe ait unsurların meydana getirdiği kompleks bir yapı içerisinde harekete geçmektedir. Buna göre duyuşsal merak, öğrenenin nesneleri keşfetmeye yönelik yaşadığı heyecan ve endişe hallerini içerisinde barındırmaktadır ve çevrede yer alan uyaranların ne kadar dikkat çekici olduğuyla ilgilidir. Berlyne (1954a) açısından duyuşsal merak aynı zamanda, öğrenende var olan tahrik duygusunu azaltmaktadır. Öğrenen dikkatini çeken uyarıcılar sayesinde bilgiyi edinmeye yönelik yoğun bir istekle, yeni gelen bilgiyi kabullenmektedir ve yoğun bilgi edinme isteğini azaltmaktadır. Diğer yandan bilişsel merak, öğrenenler açısından nesneleri kavramalarına neden olan yollar bir tür uyaran haline dönüşmekte, bilginin anlaşılması sonucunda öğrenenin zevk duygusunu yaşamasına neden olmakta, ayrıca bilgi boşluklarına karşı öğreneni duyarlı hale getirmektedir (Reiro vd., 2006). Öğrenenin eğitim ortamlarında zihinsel kapasitesini sorgulamasına ve denetlemesini sağlamakla birlikte öğrenenin yeni bilgileri edinebilmesi için hazırlıklı olmasına neden olmaktadır. Kısacası merak, bilişsel süreçlerle ilgilidir (Cyr, 1996).

Berlyne (1960), özgül (specific) ve saptırıcı (diversive) merakın ayrımını yapmıştır. Bu ayrımın öğrenenin öğrenme yaşantısı sürecinde deneyim kazanması ile uyaran düzeyini belirleyebildiği anlaşılmaktadır. Özgül merak, bir öğrenenin bilgi ve deneyimini arttırmak için bilinmeyen soruların cevaplarını derinlemesine incelemeyi amaçlarken; saptırıcı merak, öğrenen için yeni ve zorlu uyaranları araştırarak uyarılmayı arttırmakta ve öğrenenin içsel huzursuzluğunu azaltmaktadır (Ladd, 2018). Diğer bir ifadeyle özgül merak, öğrenenin öğrenmeye yönelik ilgisini arttırırken saptırıcı merakın uyaranlardan kaynaklı bilinmezliğin ve zihinsel boşluğun meydana getirdiği huzursuzluğu azaltması nedeniyle, saptırıcı ve özgül merak, algısal ve epistemik merak ile ilişkilidir (Litman ve Spielberger, 2003).

Öğrenen, öğrendiklerini faklı alanlara transfer edebilmek, hatırlamak, ilişkilendirmek gibi bir takım beceri ve yeteneklere sahiptir. Bu noktada öğrenen, bilgiyi edinme çabası içerisindeyken keşif davranışını sergilemesine motive eden yeni bilgi ve algısal deneyim edinme isteği içerisindedir (Berlyne, 1954a; Litman ve Spielberger, 2003; Loewenstein, 1994). Bu süreçte "bilgi" olarak adlandırılan birtakım görüntülerin öğrenenin zihninde sembol olarak kalıcı iz bırakmaktadır ve uyaran 
algısını arttıran algısal merak ile temel çıktısı "bilgi" olarak adlandırılan epistemik merak türü meydana gelmektedir (Berlyne, 1954a). Dolaysıyla merakın temelinde duyuşsal- bilişsel ve motivasyonel yapılar yer almaktadır. Ancak hangi durumda bu yapıların ortaya çıktığı, merakla ilgili sorgulanması gereken önemli bir konudur.

Algısal merakı harekete geçiren nokta uygun uyaranlardır (Berlyne, 1960). Bu noktada, öğrenenin algısal olarak kendisine farklı gelen 1şık ses vb. uyaranlar aracılığıyla, bilgiyi edinmek için keşif davranışını sergilemesine teşvik etmekte, gerçeklik algısını tamamlama hususunda öğreneni motive etmektedir. Diğer yandan epistemik merakın temel amacı öğrenenin bilgi arayışına yöneltmektir (Reiro vd., 2006). Bu noktada epistemik merak, ilgi ve yoksunluk olmak üzere birbirinden farklı iki alt faktörünü araç olarak kullanmaktadır. Bu nedenle algısal meraktan farklı olarak epistemik merakın, öğrenene bilgi edinme sürecinde alternatifler belirlemesine olanak sağlaması söz konusudur.

\section{Epistemik Merak}

Bilgi edinme sürecinde öğrenenin aklı ve bilişsel kapasitesi ön plandadır. Öğrenenin zihnindeki gizli düşüncelerin açığa çıkarılması için dışsal kaynaklı girişimleri ile öğrenenin gerçek yaşam koşullarında akıl ve deneyimlerinin etkileşimiyle içsel kaynaklar sonucunda öğrenme gerçekleşmektedir. Bu durum, idealist ve pragmatistlere göre, zihindeki bilgilerin öğretmenin soracağ1 sorularla açığa çıkarılması veya öğrenenin problemleri çözmek için yaptığı uygulamalar ile çevreyle kurduğu ilişkiler sonucu bilgiyi zihninde oluşturmasıyla açıklanmaktadır (Gutek, 2014). Öğrenme süreci içerisindeki öğrenenin, öğretmen vb. kişiler tarafından belirlenen yöntemlerle veya keşfetme çabası sırasında edindiği tecrübeler, ilgi veya geliştirdiği yöntemler ile bilgi edinmeye yönelmektedir. Öğrenenin bilgi edinme yöneliminde epistemik merakın varlığı, geleneksel ve çağdaş öğrenme yaklaşımlarına ait metotlar açısından sorgulanmaktadır.

Epistemik merak, öğrenenin içsel çatışma yaşamasıyla meydana gelen dürtülerle oluşmaktadır ve bu dürtü, öğrenenin edindiği bilgiler sayesinde azaltılmaktadır (Berlyne, 1954a). Öğrenenin bilinmezlik nedeniyle yaşadığı harekete geçme- geçmeme ikilemi, harekete geçme dürtüsünün baskın gelmesi sonucu, öğrenenin edindiği yeni bilgiler ile ortadan kalkmaktadır. Diğer yandan epistemik merakın, öğrenenin karşılaşılabileceği durumlarda davranışına yön veren içsel sembolik tepkilere neden olmaktadır (Berlyne, 1966). Öğrenenin karşılaştığ 1 uyaranlara karşı verdiği tepkilerin sürekliliğiyle epistemik merak, öğrenmenin gerçekleştiği durumlarda meydana gelmektedir. $\mathrm{Bu}$ nedenle, geleneksel öğretime dayalı yöntemler (Sokratik diyalog, tartışma vb.) öğrenenlerdeki düşünce yapılarının farkına varması için uyarılmasına katkı sağlamakta, öğrenenler tarafından gerçekliğin sistematik disiplinler kanalıyla araştırılmasına imkân sunmaktadır (Gutek, 2014). Ancak epistemik merakın etkisiyle, öğrenenin yaşadığı bilgi yoksunluğu içsel huzursuzluk yaşamasına neden olması sonucu öğrenen tarafından elde edilen bilginin değeri belirlenebilmektedir (Litman, 2010). Bu aşamada öğrenen, epistemik merak aracılığıyla önceki öğrenmeleri sonucunda edindiği bilgilerin niteliğini, öğrenilmemiş, zihinde eksik kalan yönlerini zihinsel işlemlerle (hatırlama, geri çağırma vb.) incelemektedir. Ancak epistemik merakın dürtü halinde açıklanması, kavramsal olarak epistemik merakı tanıyabilmede bazı sinırlılıklara neden olmaktadır. Litman'a (2018) göre, sadece dürtüler ve optimal uyaranla yapılan açıklamaların, merakın doğasını yeterli derinlikte inceleyememektedir.

Çağdaş öğrenme yaklaşımlarında, öğrenen faktörü ve öğrenme çevresi bilgiyi yapılandırma süreci içerisinde önemlidir. $\mathrm{Bu}$ nedenle öğrencilere çeşitli öğrenme tecrübesi yaşayacakları yapılandırılmış ortamlar sunulmalıdır (Schunk, 2009). Böyle ortamlarda öğrenenin herhangi bir problem karşısında o problemin çözümüne kaynaklık eden bilgileri araştırmacı kimliğe bürünerek elde etmesi gerekmektedir. Bu süreçte öğrenen, öğreneceği olguları kendi ilgi ve yeteneğine göre seçmektedir (Sönmez, 2005).

Öğrenme sürecinin sorumluluğunu üstlenen öğrenen, elde ettiği bilgileri zihninde yapılandırmakta veya zihninde yeniden o bilgiyi inşa etmekte, bu esnada anlayamadığ 1 veya kendisine karmaşı gelen bilgiyi keşfetmeye devam etmektedir. Epistemik merak ise entelektüel ilgiyi teşvik 
etmesi veya bilgi yoksunluğu koşullarını ortadan kaldırması beklenen yeni bilgileri (örneğin, kavramlar, fikirler ve gerçekler) elde etme arzusudur (Litman, 2012). Bu arzu sayesinde öğrenen, zihnindeki bilgiyi yapılandırmakta, sorgulamakta, araştırmakta, hipotez kurmakta, akranlarıyla paylaşmakta ve aldığı dönütler doğrultusunda zihnindeki bilgileri yeniden yapılandırmaktadır. Ayrıca öğrenenin, hem zihnindeki boşlukları tamamlaması hem de bilgiyi içselleştirerek entelektüel donanımı açısından gelişmesine imkân sağlamaktadır.

Epistemik merak, kendi içerisinde birbirleriyle ilişkili birden fazla olguyu barındıran bir yapıdır (Mussel, 2010). Bu yapı içerisinde, ön plana çıkan olgular bilişsel fonksiyonlar ve öğrenen ilgisidir ve epistemik merakın birbiriyle bağlantılı olan ilgi ve yoksunluk hissini barındıran alt faktörleri bulunmaktadır (Litman, 2010; Litman ve Silvia, 2006). İlgi tipi epistemik merak, öğrenenlerin kendileri için yeni bir şeyler öğrenme firsatı bulduklarında meydana gelmektedir (Litman, 2018; Litman ve Jimerson, 2004). Bu açıdan incelendiğinde öğrenme için hangi durum ve koşulun uygun olduğu epistemik merakın oluşumu bakımından belirsizlik göstermektedir. Ayrıca öğrenenin yeni öğrenmelerinden zevk almalarıyla epistemik merak ilişkilidir (Schneider, Von Krogh ve Jäger, 2013). Böylece epistemik merak kişisel ilgi alanları ve öğrenme tercihleriyle ilgili bir kavram haline gelmektedir. Öğrenme firsatlarını elde etmesiyle birlikte öğrenen, kendi öğrenme amaçlarını belirleyebilmekte, edinebildiği bilgileri hangi eski bilgilerle ilişkilendirebileceğine karar vermektedir. Öğrenme firsatlarını değerlendirmek isteyen öğrenen, Litman'a (2018) göre ilgi tipi epistemik merakı sayesinde bilinmeyen durum ve olgulara iyimser değerlendirme yapmakta, risk alabilmekte ve öz denetim stratejileri belirlemekte ve öğrenme amaçlarını eğlenmek amacıyla belirleyebilmektedir.

Yapısal olarak öğrenenin zihninde oluşturduğu bilgi algısının bütünlüğünü korumayı ve yeni bilgileri uyumlu şekilde zihnindeki algı kalıbına yerleştirmektedir. Ancak bazı durumlarda öğrenen, zihninde oluşturduğu kalıplarda bilinmezlikten kaynaklı boşluklar veya anlamlandıramadıkları bilgi kalıplarıyla karşılaşmaktadır. Yoksunluk tipi merak, öğrenenin yeni karşılaştı̆̆ anlamlandıramadı̆̆ını fark ettiği zaman ortaya çıkmaktadır (Litman, 2018). Çünkü Yoksunluk tipi epistemik merak, öğrenenin zihinsel anlamda farkındalık yaşadığı boşluğun tamamlanmasına kadar deneyimlediği rahatsız edici bir duygudur. Ayrıca öğrenenin yaşadığı belirsizlik duygusundan kurtulma çabasıdır ve bu yüzden öğrenen, belirsizlik koşullarını ve bilgi yoksunluğuna neden olan tüm koşulları ortadan kaldırmak için yeni olgu, kavram veya fikirleri elde etme arzusuna sahiptir (Litman, 2012; Richards, Litman ve Roberts, 2013). Öğrenmeye yönelik arzu duyma durumu olan ilgi tipi epistemik meraktan ziyade yoksunluk tipi epistemik merak, öğrenenin bilişindeki yapıyı tamamlama çabasına kaynaklık etmektedir. Başka bir deyişle yoksunluk tipi epistemik merak, öğrenenin istediği eksik olan bilgi parçalarına ulaşıp öğrenenin kendisini tatmin edene kadar zahmetli hale gelen rahatsız edici bir bilme ihtiyacını yansıtmaktadır (Litman, 2005; 2008; 2018). Epistemik merakta olduğu gibi öğrenenin kendi öğrenme sürecini düzenlemesi ve kontrol etmesi veya bunlarla ilgili birtakım stratejiler geliştirmesini sağlayan unsurları içerisinde barındırmaktadır.

Sonuç olarak epistemik merak, öğrenenin öğrenmesine farklı açılardan kaynaklık etmektedir. Bunu yaparken öğrenenin ilgisi ve bilgiye sahip olma derecesinin zihinde yarattığ boşluğu tamamlama çabasına girmesine neden olmaktadır ve öğrenme sürecinin etkili şekilde işleyişine kaynaklık eden bir unsur haline gelmektedir. Epistemik merak bu sorgulamalar neticesinde hem öğrenme ve öğretme süreci açısından hem de öğrenenle ilgili birtakım faktörler açısından incelenmesi önemli hale gelmektedir.

\section{Epistemik Merakın Öğrenme ve Öğretme Sürecindeki Rolü}

Eğitim programları açısından epistemik merakın varlığını sorgulamak, çağdaş eğitim anlayışına göre incelenmesi gereken önemli bir konu haline gelmiştir. Çünkü öğrenenin araştırmasına ve çevreyi deneyimlemesine kaynaklık eden meraklı bir zihin, öğrenme sürecinde her zaman etkindir. $\mathrm{Bu}$ durumda öğrenen temelli öğrenme ve öğretme sürecinde, araştırma faaliyetine destek veren öğretim uygulamalarının epistemik merakı ne derece desteklediğinin incelenmesi gerekmektedir. 
Öğretme ve öğrenme sürecinde öğretim programında yer alan hedefler dışında öğrenenin içsel olarak belirlediği öğrenme hedeflerinin epistemik merakla ilişkisi olduğu anlaşılmıştır. Koo ve Choi'nun (2010) araştırmasında epistemik merakın öğrenenin öğrenme niyetiyle ve motivasyonu üzerinde olumlu bir etkiye sahip olmasıyla açıklanmıştır (Koo ve Choi, 2010). Diğer yandan, öğretim programında belirlenen hedefler bağlamında epistemik merak açılanmıştır. Örneğin ilgi tipi epistemik merak, öğrenenin ders başarısı ile öğrenme sürecine olan ilgisinin artmasına neden olan üst düzey öğrenme hedeflerinin geliştirilmesiyle ilişkilidir (Litman, 2008; 2012). Bu görüş doğrultusunda epistemik merak, öğrenme hedeflerinin yapısı ve niteliği ile öğrencinin öğrenme niyetinin tutarlılığını nasıl etkilediği inceleme konusu haline gelmektedir. Bunun nedeni şudur ki çözümleme (analiz), yaratma (sentez) ve değerlendirme basamağında üst düzey hedeflerin yer alması (Bümen, 2006; Tutkun, 2012), bir şekilde epistemik merakın harekete geçirilmesi için ön koşuldur ve aktif öğrenme süreçlerinin işe koşulduğu öğretim uygulamalarına bağlı olarak epistemik merak, akademik başarıyı olumlu yönde etkilemektedir (Ceylan, Sağırekmekçi, Tatar ve Bilgin, 2016; Elmalı Özsaray, 2016; Powell ve Nettelbeck, 2014).

Öğretim stratejileri, öğrenme hedeflerinin düzeylerine bağlıdır ve öğrenen ve öğretmen açısından birtakım sorgulamaları içeren üç farklı (sunuş, buluş ve araştırma inceleme) öğretim süreci içerisindedir (Sönmez, 2011). Öğretim stratejileri aracılığıyla öğretim ve öğrenme sürecinin giriş aşamasından değerlendirmeye kadar şekillendirilmesi nedeniyle epistemik merakın sürece katkı sağladığı düşünülmektedir. Yapılan çalışmalara göre, öğrenme sürecinde öğretmenlerin araştırma stratejisini temel alarak uyguladığı bir öğretimde, öğrenenlerin merak duygusu artmaktadır (Taşkın, 2016; Zion ve Sadeh, 2007). Bu bulgular, öğretmenin öğretim sürecini belirlerken tercih ettiği öğretim stratejilerinin epistemik merak düzeyinin gelişimi açısından önemli olabileceğine dair somut bir bulgu sunmaktadır.

Öğretmenler açısından öğrenenlerin hem birden fazla duyu organlarının harekete geçirilmesi hem de problemin çözümüne ilişkin argüman sunabilmesi için öğreneni bilgi arayışına teşvik ediği bir öğrenme ortamı oluşturulması önemli bir konudur. Böyle bir öğrenme ortamında karşılaştığ1 problemlere çözüm arayışına giren öğrenen, düşünme ve problem çözme davranışını epistemik merak ile ilişkili olarak gerçekleştirmektedir (Leherissey, 1971; Akt. Cyr, 1996). Çünkü öğrenen bu süreçte epistemik merak vasıtasıyla bilginin entelektüel arayışını gerçekleştirmektedir (Cyr, 1996). Yani bir öğretmenin hazırladığ 1 öğretim planı içerisinde öğrenenin düşünmesini sağlayacak (örnek olay, problem vs.) etkinliklerle öğrenenin epistemik merak derecesi artmaktadır ve bilgi arayışı için öğrenen aktif hale gelmektedir. Ayrıca epistemik merak, öğrencilerin öğrenme firsatlarına yaklaşmasını sağlamaktadır ve öğrenene yeni fikirler hakkında düşünmesi, soru sorması ve problem çözmesi konusunda motivasyon sağlamaktadır (Richards vd., 2013).

Epistemik merak, öğrenenin yeni karşılaştığı, bilmediği ve kullanılmamış olduğu fikirleri öğrenmeye, mevcut olan bilgi boşluklarını ortadan kaldırmaya ve bilimsel problemlerine çözüm üretmesine motive eden bir bilme arzusudur (Berlyne, 1954a; Litman, 2008; Loewenstein 1994). Bu açıdan incelendiğinde öğrenme sürecinin belki de en önemli aşaması öğrenene sunulan araştırma problemlerinin niteliği ve etkililiğidir. Öğrenene sunulan bir problemin etkililiği öğrenenin zihinsel kapasitesini geliştirmeye katkı sağladığı gibi epistemik merakını da geliştirmektedir. Litman vd.'ne (2005) göre kendisine sunulan araştırma probleminin çözümü karşısında öğrenen yeni ve farklı sorular, alış1lagelmemiş fikirler, belirsiz ifadeler ve çözüme ulaşmayan sorunlarla karşılaşmaktadır ve böylece, epistemik merak derecesi artış göstermektedir. Kendisine sunulan nitelikli bir araştırma problemi karşısında öğrenen, çözüme ilişkin uygun bilgi arayışına girmekte, içsel sorgulamalar yapmakta, zihninde oluşturduğu soruları çevresindekilere yöneltmektedir. Dolayısıyla öğrenme sürecinde epistemik merakı yüksek olan öğrenciler düşük olanlara kıyasla derslerde daha fazla soru sorma eğilimi göstermektedirler (Spielberger vd. 1981; Akt. Schneider vd., 2013).

Derslerde öğrenciye sunulan bir problemin çözümüne kaynaklık eden öğretim teknikleri, öğrenci- öğrenci, öğrenci- öğretmen arasında etkileşim yaşanmasına kaynaklık etmektedir. $\mathrm{Bu}$ etkileşimle birlikte öğrenenin epistemik merakının etkilendiği düşünülmektedir. Örneğin tartışma tekniğinin uygulandığı bir sınıf ortamında yapılan grup çalışmalarında, öğretmen ve öğrenciler 
arasında öğrenenin eski bilgileri ile yeni bilgiler arasında bazı çatışmalar meydana gelmektedir (Johnson ve Johnson, 1979). Yani hem öğrenenler arasında hem de öğretmen- öğrenen arasında bir tür kavramsal çatışma* yaşanmaktadır ve bu yüzden, anlaşmazlıklar meydana gelmektedir (Kavramsal çatışma, öğrenenin zihnindeki uyumsuz fikirlerin var olması ve uyumsuz fikirlerin uzlaştırılması sonucu meydana gelmektedir (Berlyne, 1957). Öğrenen açısından öğrenme sürecinde yaşanan kavramsal çatışmalar ve anlaşmazlıklar, bilgi edinme sürecinde öğreneni rahatsız olmasına veya öğrenenin ilgisini çekmeye neden olmaktadır. Böylece, öğrenen ister istemez kavramsal çatışmaların çözümüne katkı sağlamayı amaçlamaktadır. Bu nedenle öğrenen, aktif bir şekilde bilgi edinmek için motivasyon sağlamakta (Berlyne, 1966), tartışma tekniğiyle epistemik merakını harekete geçirmektedir (Lowry ve Johnson, 1980).

Öğrenme sürecinde öğrenenin, öğrenmeyle ilgili tüm aşamaları doğrudan deneyimlemesi önemli olması nedeniyle drama, deney gibi öğretim teknikleriyle öğrencinin epistemik merak düzeyinin birbirleriyle ne tür ilişkide olduğunu incelemek gerekir. Sarışan-Tungaç vd. (2019) araştırmasında bilimsel konulara yönelik düzenlenen yaratıcı drama etkinliklerinin öğrencilerin merakını olumlu yönde etkilediği sonucuna ulaşılmıştır. Bu süreçte canlandırılan karakter, dinleyiciler için dikkat çekici ve ilgi duygusu geliştirmesini sağlamakta, karakter üzerinden ilgili konunun bilinmeyen yönleri öğrenen tarafından fark edilmektedir. Diğer yandan deneyin, belli bir problemin çözümü için üretilen hipotezin belirli bir ortamda bireysel veya grupla test edildiği bir teknik olmasıyla (Sönmez, 2011), deneysel yöntemlerle yapılan öğretim uygulamalarının epistemik merakla ilgili olduğu düşünülmektedir. Bu teknik öğrenenin araştırma probleminin çözüm yollarının geliştirilmesine yönelik öğrenende ilgi uyandırması ve deneysel süreçteki eksikliklerini fark edebilmesi için yoksunluk hissini arttırabilmesi nedeniyle drama, deney gibi uygulamaya dayalı tekniklerin, öğrenenin epistemik merakını harekete geçirebilmesi mümkündür.

Öğrenenin doğrudan bilgiyi edinemeyeceği durumlarda izlenecek belki de en iyi yol öğrenme ortamını gerçeğe en yakın olmasını sağlamaktır. Bu bağlamda müze gibi yerler, sosyal bilimlere bağlı derslerde öğreneni gerçeğe en yakın öğrenme çevresine ulaştırabilecek ortamlarını sunmaktadır. Yapılan araştırmalara göre, müze vb. gezi ve gözleme dayalı ders dışı teknikleri, öğrencilerin ilgisini çekme ve öğrenmeye motive etme konusunda önemlidir (Taşpınar, 2012; Yıldızlar, 2011). Müzelerde sergilenen objeler, nesneler ya da simülasyon merkezlerinde yer alan görsel ve işitsel unsurlar, öğrencilerin epistemik meraklarının harekete geçmesinde önemli bir yere sahiptir. Diğer yandan bir suç müzesinde yapılan araştırmada, objenin gerçek kullanım alanından getirilmiş olması, nesnenin çekici hale getirilmesi, canlandırma, drama vb. yöntemlerle öğreneni karakterlerle özdeşleştirmesi, öğrenenin merak etmesini sağlamaktadır (Yun, 2018). Sonuç olarak epistemik merakın harekete geçmesi için öğrenme çevresinde sosyal bilimlere yönelik konularda öğrencileri karakterler veya olaylarla özdeşleştirmek, etkinliklerde kullanılan nesnelerin niteliği, öğrencilerin duyuşsal olarak bilgiye yönelik arzusuna veya bilgi yoksunluğuna dayalı bilgi arayışına götürebilecek çeşitli öğretim yöntem ve tekniklerinden yararlanılmalıdır.

Öğrenme ortamları açısından epistemik merakın incelenmesi gereken diğer bir nokta, öğretim materyali olarak tercih edilebilen ve başlı başına öğrenme ortamı olabilen teknolojik araçlardır. Koo ve Choi'nin (2010) araştırmasında epistemik merak aracılı̆̆ıyla öğrenenin sahip olduğu motivasyonun, internet siteleri vasıtasıyla öğrenenin hedefe ulaşma potansiyeliyle ilişkisinden bahsedilmektedir (Koo ve Choi, 2010). Yani öğrenenin girdiği internet sitelerinin görsel ve işitsel unsurlar bakımından niteliği öğreneni o sitede yer alan bilgiyi edinmesini sağlamaktadır. Öğretmenin öğrencilerine önerebileceği veya ders etkinliği olarak sunabileceği sitelerin öğrenenin merakını doğrudan etkileyebilmektedir. Lee ve Kozar (2009) tarafından yapılan çalışmada hedef kitlenin niteliğine göre yapısının ve içeriğinin kolaylıkla anlamlandırılmasıyla oluşturulan web sitelerin öğrenenlerin meraklarını arttırdığını göstermektedir. Bu bulgu bir bakıma öğrenenin ilgisinden hareketle oluşturulacağı için epistemik merakın teknolojik araçların sağladığı uygulamalarla ilişkili olabileceğini düşündürmektedir. Çünkü video oyunları gibi uygulamalar öğrenenin ilgi tipi epistemik merakı ve performansıyla ilişkilidir (Huck, Day, Lin, Jorgensen, Westlin ve Hardy III, 2020). Online ortamlarda hazırlanan uygulamalar, öğrenenin duyu organlarını harekete geçirerek öğrenenin ilgisini yeni bilgi arayışına yönlendirmekte, 
bu doğrultuda öğrenenin öğrenme hedeflerine ulaşmasını ve öğrendiklerini performans halinde göstermesine katkı sağlamaktadır.

Teknolojik araçlarda epistemik merak açısından incelenmesi gereken diğer bir husus, epistemik merakın öğrenenin ilgisi, kişilik özelliği veya zihninde var olan bilgi eksikliklerinin yazılım uygulamaları aracılığıyla meydana gelme derecesi veya sıklığıdır. Bunun nedeni entelektüel anlamda bilgi arayışına giren çevrim içi grup topluluğunda ilgi tipi epistemik merakı yüksek olan grubun bilgi düzeyine katkı sağlayan faaliyetlerde bulunurken, kaygı faktörü devreye girdiği için yoksunluk tipi epistemik meraka sahip grup üyelerinin öğrenme sürecinde çekimser kalarak gizlenme davranış1 sergilemesidir (Schneider vd., 2013). Bu husus epistemik merakın iki şekilde sorgulanmasına neden olmaktadır. Birincisi, bir topluluk içerisinde iletişim becerileri güçlü veya zayıf olan bireylerin girişimcilik vb. kişisel özelliklerinden dolayı ilgi veya yoksunluk tipi epistemik meraklarını harekete geçirmesidir. Yani kişilik özelliklerinin epistemik merak üzerinde yönlendirici bir rol üstlenmesidir. İkincisi ise "Epistemik merakın olumlu veya olumsuz, baskın veya çekinik kişilik özellikleri üzerinde belirleyici midir?" sorusuna gelebilecek muhtemel yanıtlardır. Çünkü epistemik merak tek başına mı yoksa başka bir değişken aracılığıyla mı çekinik kişilik özelliklerini tetikleyebildiği merak edilen başka bir durumdur.

Çağdaş öğrenme anlayışına göre öğretim programlarının bütün unsurları öğrencinin birtakım becerilerinin geliştirilmesine yönelik oluşturulmaktadır. Bu beceriler öğrencilerin "yaratıcılık, problem çözme, eleştirel düşünme, üst düzey düşünme" gibi becerilerini içerisinde barındırmaktadır (Güneş, 2012). Ancak bu beceriler her ne kadar birbirlerinden farklı ifadelerle adlandırılsa da kendi içerisinde temel aldığ 1 bazı ortak noktalar vardır. Bu noktalar yapılan araştırmalarda problem çözme ve karar verme olarak belirlenmiştir (Seferoğlu ve Akbıyık, 2006). Sonuç olarak epistemik merakın problem çözme ve karar verme sürecinde zihinsel yapıdaki rolünün aydınlatılması gerekmektedir.

Metabilişsel düşünme becerisiyle öğrenen, bilişsel olarak kendisinde var olan bilgi ve becerileri ve o bilgileri nerede, nasıl ne zaman kullanacağını farkındalığına sahiptir (Schunk, 2009). Yani öğrenen kendi bilişsel kapasitesine bağlı olarak karşılaştığı bir problemin çözümü için sahip olduğu potansiyelin farkında olması nedeniyle öğrenme üzerine kararlar alabilmektedir. Yapılan araştırmalarda epistemik merakın rolü, öğrenenin hafızasında meydana gelen boşluğu fark etmesi (Kang, Hsu, Krajbich, Loewenstein, 1994; Loewenstein, McClure, Wang ve Camerer, 2009) veya zihnindeki bilgi tutarsızlıklarını kabul etmesi sonucunda ortaya çıkmaktadır (Litman, 2005). Dolayısıyla epistemik merakın öğrenenin hafızası ile ilişkili olduğu görülse de öğrenmenin kalıcılığı açısından epistemik merakın ne derece etkili olduğu, diğer biliş yapılarıyla ne tür ilişki içerisinde olduğu açıklanması gereken konulardan birisidir.

Epistemik merak, öğrenenin yaşadığı metabilişsel duygular ile bilgi arayışını sürdürmesinin devamlılığını sağlamaktadır (Metcalfe, Shwartz ve Bloom, 2017). Öğrenenin zihinsel olarak bilgiye sahip olup olmaması konusunda farkındalık yaşamaktadır. Bilişsel becerilerin işleyişi sürecinin etkililiği konusunda yaşanan hisler, epistemik merak aracılığıyla edinilen yeni bilgiler sayesinde en aza inene kadar devam ettirildiği anlaşılmaktadır.

Yapılan araştırmalarda, öğrenenin bilgiyi bilip bilmediğini kabul etmesi (Feeling of knowing) ilgi tipi epistemik merak, öğrenenin bildiği bilginin farkında olup zihninden o bilgiyi çağırıp söyleyememe düzeyi (Tip of the tongue) yoksunluk tipi epistemik merak ile ilişkilendirilmektedir (Litman, 2009; Litman, Hutchins ve Russon, 2005). Ancak öğrenenin bilme hissi ile dilinin ucunda hissiyatını hangi durumlarda yaşadığı ve her iki hissin öğrenene hangi durumda keyif vereceği hangi durumda hoşnutsuzluk yaşayacağı konusunda bir belirsizlik söz konusudur. Öğrenme ortamında öğrenene sunulan her türlü öğretme süreci değişkenlerinin her bir öğrencide ne tür hissiyata neden olabileceği konusunda kesim ayrım yapılması zordur. Özellikle Litman vd. (2005) ve Litman (2005; 2009) tarafından içsel sıkıntı olarak nitelendirilen "dilimin ucunda" (Tip of the tongue) durumu, Metcalfe vd.'ne (2017) göre öğreneni daha fazla ve derinlemesine bilgi anlayışına sevk etmektedir. Dilimin ucunda durumunun içinde bulunduğu koşullara göre ilgi tipi epistemik merak, öğreneni 
harekete geçiren bir unsur haline gelmektedir. Diğer yandan koşula ve duruma bağlı olarak öğrenenin hissiyatını ve metabilişsel yapısının ne şekilde ilişkili olduğunun sorgulanması gerekmektedir.

Bilgi arayışı sürecinde öğrenenin yaratıcı bir şekilde, farklı alternatifleri göz önünde bulundurarak bilgiye ulaşması eğitim programları açısından önemli becerilerden birisidir. Yaratıcı düşünme öğrenenin özgün, akıcı ve mantıklı, oldukça esnek ve benzersiz bir şekilde düşünebilmesini sağlayan beceridir (Sönmez, 2011, s. 173). Yaratıcı düşünme becerisiyle birlikte bilimsel ve sosyal problemlere alternatif ve yaratıcı çözümler üretmesi hususunda öğreneni bilgi arayışına yönelimini sağlayan epistemik merakla ilişkili etmenlerin incelenmesi gerekmektedir.

Epistemik merak, öğreneni bir soruna çözüm arayışına teşvik ettirmektedir (Loewenstein, 1994). Öğrenenin alternatif çözüm ararken eski ve yeni edindiği bilgileri sentezleyerek yeni bir bilgi meydana getirdiği varsayıldığında, epistemik merakın yaratıcı düşünme beceriyle ilişkisi söz konusudur. Öğrenen, karşılaştığı bir soruna yaratıcı düşünme becerisi sayesinde birbirinden farklı alternatif çözüm üretme çabasına girmektedir. Bu konuyla ilgili yapılan bir araştırmada, ilgi tipi epistemik merakın yaratıcı problem çözme ve yaratıcı performans üzerinde olumlu bir etkiye sahipken, yoksunluk tipi epistemik merakın yaratıcılıkla bir ilişkisi bulunmamaktadır (Hardy III, Ness ve Mecca, 2017). Öğrenen, sürecin sonunda hoşuna giden, araştırmaktan ve entelektüel donanımını arttırmasından memnun olacağı bir bilgiyi edinmek için problemlere alternatif çözümler üretebilmektedir. Öğretim sürecinde öğrenciye sunulacak problemlerin niteliği, öğrenenin birden fazla çözüm üretmesine veya öğrenme ürünü meydana getirmesi konusundaki önemi, epistemik merakın bu süreçte hangi ara değişkenlerle birlikte değişim gösterebileceği hususunda sorgulanması gereken bir konu haline gelmiştir.

Yaratıcılığın incelenmesi gereken diğer bir nokta özgün eserlerde meydana getirme konusunda epistemik merakın ne tür bir rolü olduğudur. Gerçekleştirilen araştırmalara göre merak, tasarım eğitimi gibi öğrencilere sunulan derslerle ilişkilidir (Day, Langevin, Maynes ve Spring, 1972; Kashdan ve Fincham, 2002; Rinkevich, 2014; Smith, 2010) ve özgün eserler oluşturma sürecinde öğrenene psikolojik destek sunan bir yapıya sahiptir (Kashdan ve Fincham, 2002). Bu aşamada öğrenene öğretim sürecinde sunulacak olan etkinliklerin ilgisini harekete geçirecek şekilde belirlenmesi, öğrencinin hoşuna giden materyalleri kullanmasına imkân sağlayacak etkinliklerin yaptırılması öğrenenin zihnindeki eksik bilgileri tespit etmesine neden olabilir. Aynı zamanda yaratıcılık odaklı eğitimin epistemik merakın hangi faktörünü harekete geçireceği belirsizdir. İlgi ve yoksunluk tipi epistemik merakın yaratıcılık konusunda farklı değişkenlerle derinlemesine incelenmesi bir ihtiyaç haline gelmektedir.

Öğrenme ve öğretme süreci içerisinde epistemik merakın etkisiyle öğrenenin metabilişsel ve yaratıcı düşünme gibi birtakım becerilerinin gelişebildiği anlaşılmıştır. Ancak yapılan incelemelerde her ne kadar öğrenenin epistemik merakının dışsal etkinlikler, yöntem ve teknikler aracılığıyla geliştiği görülse de bu durumun epistemik merakın etkililiğini açıklama konusunda yetersiz kaldığını belirtmek mümkündür.

Modern eğitim anlayışında kendi varlığının farkında olan bireyler, kendisine ait kişilik ve kimlik yapılarını tanımlaması sonucunda seçim özgürlüğüne sahip olmaktadır (Gutek, 2014). Öğrenme sürecini özerk olarak gerçekleştirebilen öğrenenin kişilik özellikleri açısından epistemik merakla ilişkisi söz konusu olması nedeniyle öğrenenin kişilik yapılarının öğrenme tercihlerini ne şekilde etkileyeceği ve daha da ötesinde ögrenmeye yönelimini ne yönde etkileyeceği önemli bir konudur. Aktif öğrenme yaklaşımına göre öğrenenin bireysel gelişim sürecinde öğrenmedeki tüm sorumluluğu üstlenmesi, kendisi ve öğrenme süreci hakkındaki değerlendirme yapması sebebiyle öğrenen öz düzenlemesi ve öğrenmede özerkliğini kapsamaktadır. Özerk olarak öğrenenin öğrenme sürecine ait tüm sorumlulukları üstlenebilmesi, öğrenme konusunda ihtiyaç analizi yapmasına, öğrenimini kendi düzeyine göre planlamasına neden olmaktadır. Ayrıca öğrenenin, öğrenme sürecinde rekabet etme gibi bazı kişisel özelliklerini yansıtmasına neden olmaktadır (Holec, 1981). Dolayısıyla epistemik merakın kişilik özellikleri aracılığıyla öz düzenleme ve özerklik arasında ilişki kurabilen bir yapıya sahip olduğu anlaşılmıştır. 
Johnson'un (2011) araştırmasına göre, tüm kişilik özellikleri epistemik merak üzerinde arabulucu bir rol üstlenmemektedir. Lauriola, Litman, Mussel, Santis, Crowson ve Hoffman (2015) tarafından yapılan araştırmada elde edilen bulgular, Johnson'1 (2011) desteklenmektedir. Örneğin ilgi tipi epistemik merak, öğrenendeki olumlu sonuç beklentisi, risk alma ve eğlence arayışı gibi özelliklerle pozitif yönde; yoksunluk tipi epistemik merakın, duygusal kısıtlama, düşünceli değerlendirme, olumsuz sonuçlar ile potansiyel riskler konusunda öğrenenin endişeleri gibi kayg1 pozitif, eğlence arayışı ile negatif yünde ilişkilidir (Lauriola vd., 2015). Özetlemek gerekirse, epistemik merakın alt faktörlerinin yapısıyla uyumlu olarak, olumlu, girişimciliğe teşvik eden kişilik özellikleri ilgi tipi, öğrenenin kaygıdan kaynaklı öğrenme yönelimi sergilemesine neden olabilecek kişilik özellikleriyle yoksunluk tipi epistemik merak ilişkilendirilmektedir.

Epistemik merak, vicdanlılık gibi kişilik özellikleriyle öğrenme konusunda arabulucu bir rol üstlenmektedir (Hassan, Bashir ve Mussel, 2015). Epistemik merakın ahlaki kişilik özelliklerini içerisinde barındırmasıyla duyuşsal alana hitap eden ders hedefleri ile değerler eğitimi gibi eğitsel konularla ilişkili olabileceğine yönelik somut bulgular bulunmaktadır. Epistemik merak kişilik özellikleriyle olan ilişkisi sonucunda toplumun birtakım değerlerini içerisinde barındıran bir yapı haline gelmektedir. Ayrıca epistemik merakın, öğrenme sürecinde kişilik gelişimini sağlayan bir araç görevi üstlenmesi mümkündür.

Sonuç olarak, epistemik merak, insanın bilişsel yapısı ve kişilik faktörleriyle birlikte öğrenme ve öğretme sürecine birçok açıdan bağlantılı olduğu anlaşılmaktadır. Ayrıca, epistemik merakın öğrenme sürecine bağlı değişkenlerle arabulucu bir rol üstlendiği ve öğrenme- öğretme sürecini kapsayan bir yapı haline geldiği anlaşılmaktadır. Epistemik merakın bu yapısı ve öğrenme sürecindeki rolleri her ne kadar yurtdışında yapılan araştırmalarla açıklanmaya çalışılsa da, Türkiye'de gerçekleştirilecek araştırmalarda, epistemik merakın öğrenme sürecindeki rolüne aracılık eden değişkenlerin neler olabileceği sorgulanmalı ve amprik çalışmalarla incelenmelidir.

Açıklama: $\mathrm{Bu}$ çalışma birinci yazarın 2020 yılında Doç. Dr. Osman Yılmaz Kartal danışmanlığında Çanakkale Onsekiz Mart Üniversitesi Eğitim Bilimleri Enstitüsü Eğitim Bilimleri Anabilim Dalı'nda yürüttüğü "Lise Öğrencilerinin Öğrenme Yaklaşımları tercihlerinde Metabilişsel Farkındalık ile Epistemik Merakın Etkisi” başlıklı yüksek lisans tezinin teorik çerçevesinden üretilmiştir.

\section{Kaynaklar}

Augustine, St. (1943). The confessions of St. Augustine (J. G. Pilkington, Trans.). New York: Liveright.

Berlyne, D. E. (1954a). A theory of human curiosity. British Journal of Psychology. General Section, 45(3), 180-191.

Berlyne, D. E. (1954b). An experimental study of human curiosity. British Journal of Psychology. General Section, 45(4), 256-265.

Berlyne, D. E. (1957). Uncertainty and conflict: A point of contact between information-theory and behavior-theory concepts. Psychological Review, 64(6), 329-339. Doi: 10.1037/h0041135.

Berlyne, D. E. (1960). Conflict, arousal, and curiosity. Mcgraw-Hill Book Company. (e-book).

Berlyne, D. E. (1966). Curiosity and exploration. Science, 153(3731), 25-33.

Berlyne, D. E. (1978). Curiosity and learning. Motivation and Emotion, 2(2), 97-175. 
Blumenberg, H. (1985). The legitimacy of the modern age. (R.B. Wallace, Trans.) Mit Press. https://books.google.com.tr/books adresinden erişilmiştir.

Bümen, N. T. (2006). Program geliştirmede bir dönüm noktası: Yenilenmiş Bloom taksonomisi. Eğitim ve Bilim, 31 (142), 3-14.

Ceylan, E., Sağırekmekçi, H., Tatar, E., ve Bilgin, İ. (2015). Ortaokul öğrencilerinin merak, tutum ve motivasyon düzeylerine göre Fen Bilgisi dersi başarılarının incelenmesi. Uşak Üniversitesi Sosyal Bilimler Dergisi, 9(1), 39-52.

Cho, K. D. (2008). Curiosity according to psychoanalysis: Blumenberg, Freud, and the destiny of an affect. New German Critique, 35(2), 191-205.

Cyr, T. A. (1996). Arousing and sustaining intellectual curiosity: A study of course design and implementation. Doctoral dissertation. Denver University.

Day, H. (1968). A curious approach to creativity. Canadian Psychology, 9(4), 485.

Day, H.I., and Langevin, H. (1969). Curiosity and intelligence: Two necessary conditions for creativity. The Journal of Special Education, 3(3), 263-268.

Day, H. I., Langevin, R., Maynes, F. and Spring, M. (1972). Prior Knowledge and The Desire For Information. Canadian Journal of Behavioural Science/Revue Canadienne Des Sciences Du Comportement, 4(4), 330-337. Doi:10.1037/h0082318

Day, H. I. (1982). Curiosity and the interested explorer. Performance and Instruction, 21(4), 1922. Doi:10.1002/pfi.4170210410

Deringöl, Y., Yaman, Y., Özsarı, İ., ve Gülten, D. Ç. (2010, Kasım). İlköğretim öğretmen adaylarının meraklılık düzeylerinin incelenmesi. International Conference on New Trends in Education and Their Implications konferansında sunulan bildiri içinde, Antalya. Erişim adresi: http://www.iconte.org/FileUpload/ks59689/File/109.pdf

Demirel, M., ve Coşkun, Y. D. (2009). Üniversite öğrencilerinin meraklılık düzeylerinin bazı değişkenler açısından incelenmesi. Mehmet Akif Ersoy Üniversitesi Eğitim Fakültesi Dergisi, (18), 111-134.

Dewey, J. (1910). How we think. Boston. MA: DC Heath.

Dewey, J. (1913). Interest and effort in education. Houghton Mifflin.

Dilmaç, B., Karababa, A. (2016). Öğrenme ve öğretmeyle ilgili temel kavramlar. G. Ekici (ed), Öğrenme-ögretme kuramları ve uygulamadaki yansımaları. Ankara: Pegem.

Edelman, S. (1997). Curiosity and exploration. Retrieved May11, 2005. https://www.csun.edu/ vcpsy00h/students/explore.htm adresinden erişilmiştir.

Elmalı Özsaray, A. (2016). Üniversite öğrencilerinin ingilizce derslerine ilişskin başartyla ilgili duyguları, bilgiye yönelik merakları ve ders başarısı arasındaki ilişkiler. Yüksek Lisans Tezi. Abant İzzet Baysal ÜniveristesilEğitim Bilimleri Enstitüsü, Bolu.

Eren, A. (2009). Examining the relationship between epistemic curiosity and achievement goals. Egitim Arastirmalari-Eurasian Journal of Educational Research, 36, 129-144. 
Eren, A. (2011) Prospective teachers' general epistemic curiosity and domain-specific epistemic curiosity: The mediating role of perceived instrumentality. In R. M. Teixeira (Ed.). Higher Education in a State of Crisis (163-183). New York, NY: Nova Publishers.

Eren, A. and Coskun, H. (2016) Students' level of boredom, boredom coping strategies, epistemic curiosity, and graded performance. The Journal of Educational Research, 109(6), 574-588, Doi: 10.1080/00220671.2014.999364.

Freud, S. (1959). On the sexual theories of children. London: Hoghart Press.

Fulcher, K.H. (2004). Towards measuring lifelong learning: The curiosity index. Doctoral dissertation, James Madison University.

Gutek, G. (2014). Eğitime Felsefi ve İdeolojik Yaklaşımlar. (Çev: N.Kale) Ütopya Yayın Evi: Ankara.

Güneş, F. (2012). Öğrencilerin düşünme becerilerini geliştirme. Türklük Bilimi Araştırmaları, 32, 127 146.

Hassan, M. M., Bashir, S. and Mussel, P. (2015). Personality, learning, and the mediating role of epistemic curiosity: A case of continuing education in medical physicians. Learning and Individual Differences, 42, 83-89.

Holec, H. (1981). Autonomy and foreign language learning. Oxford: Pergamon.

Huck, J. T., Day, E. A., Lin, L., Jorgensen, A. G., Westlin, J. and Hardy III, J. H. (2020). The role of epistemic curiosity in game-based learning: Distinguishing skill acquisition from adaptation. Simulation and Gaming, 51(2), 141-166. Doi: 1046878119895557.

Johnson, D. W. and Johnson, R. T. (1979). Conflict in the classroom: Controversy and learning. Review of Educational Research, 49(1), 51-69. Doi:10.3102/00346543049001051

Johnson, D. R. (2011). Using Eysenck's model of personality to predict epistemic curiosityand exploratory behavior. Doctoral dissertation. Northern Illinois University.

Kang, M. J., Hsu, M., Krajbich, I. M., Loewenstein, G., McClure, S. M., Wang, J. T. Y., and Camerer, C. F. (2009). The wick in the candle of learning: Epistemic curiosity activates reward circuitry and enhances memory. Psychological science, 20(8), 963-973.

Kapıkıran, Ş. ve Susar Kırmızı, F. (2019). Öğretmen adaylarının merak ve keşfetme algıları ile okuma alışkanlığına yönelik tutumları arasındaki ilişki. Ahi Evran Üniversitesi Sosyal Bilimler Enstitüsü Dergisi, 5(2), 251-265.

Kashdan, T.B. and Fincham, F.D. (2002). Facilitating creativity by regulating curiosity. American Psychologist, 5, 373-374. Doi: 10.1037/0003-066X.57.5.373.

Kashdan, T. B., Rose, P. and Fincham, F. D. (2004). Curiosity and exploration: Facilitating positive subjective experiences and personal growth opportunities. Journal of personality assessment, 82(3), 291-305. Doi: 10.1207/s15327752jpa8203_05.

Kaya, Z. (2007). Eğitimin psikolojik temelleri. (Ed) Ö. Demirel ve Z. Kaya. Eğitim Bilimine Giriş (2.Bask1). Ankara: Pegem A.

Koo, D.M., and Choi, Y.Y. (2010) Knowledge search and people with high epistemic curiosity. Computers in Human Behavior, 26(1), 12-22. 
Ladd, K. S. (2018). The experiences of students who increased curiosity during their first year of college: A grounded theory study. Doctoral dissertation, Azusa Pacific University.

Lauriola, M., Litman, J. A., Mussel, P., De Santis, R., Crowson, H. M., and Hoffman, R. R. (2015). Epistemic curiosity and self-regulation. Personality and Individual Differences, 83, 202-207.

Lee, Y., and Kozar, K. A. (2009). Designing usable online stores: A landscape preference perspective. Information and Management, 46(1), 31-41.

Leherissey, B. (1971). The effects of stimulating state epistemic curiosity on state anxiety and performance in a complex computer-assisted learning task. Tech Report No. 23, Project NR 154-280 sponsored by Personnel and Training Research program s, Psychological Sciences Division, Office of Naval Research, Arlington, VA.

Litman, J. A., and Spielberger, C. D. (2003). Measuring epistemic curiosity and its diversive and specific components. Journal of Personality Assessment, 80(1), 75-86.

Litman, J. A., and Jimerson, T. L. (2004). The measurement of curiosity as a feeling of deprivation. Journal of Personality Assessment, 82(2), 147-157.

Litman, J. (2005) Curiosity and the pleasures of learning: Wanting and liking new information, Cognition and Emotion, 19 (6), 793-814. Doi: 10.1080/02699930541000101.

Litman, J., Hutchins, T., and Russon, R. (2005). Epistemic curiosity, feeling-of-knowing, and exploratory behaviour. Cognition and Emotion, 19(4), 559-582.

Litman, J.A. and Silvia, P.J. (2006) The latent structure of trait curiosity: evidence for interest and deprivation curiosity dimensions, Journal of Personality Assessment. 86 (3), 318-328. Doi: 10.1207/s15327752jpa8603_07.

Litman, J. A. (2008). Interest and deprivation factors of epistemic curiosity. Personality and Individual Differences, 44(7), 1585-1595.

Litman, J. A. (2009). Curiosity and metacognition. In C.B. Larson (Eds.) Metacognition: New Research Developments (105-116). New York, Nova Science Publishers.

Litman, J. A. (2010). Relationships between measures of I and D-type curiosity, ambiguity tolerance, and need for closure: An initial test of the wanting-liking model of informationseeking. Personality and Individual Differences, 48(4), 397-402.

Litman, J. A. (2012). Epistemic curiosity. Invited Chapter In: S. Norbert (Ed.) Encyclopedia of the Sciences of Learning (1162-1165). New York: Springer-Verlag.

Litman, J.A. (2018). Curiosity: Nature, dimensionality, and determinants, In K.A. Renninger and S.E. Hidi (Eds.) The Cambridge Handbook of Motivation and Learning (418-441). New York, NY: Cambridge University Press.

Livson, N. (1967). Towards a differentiated construct of curiosity. The Journal of Genetic Psychology, 111(1), 73-84. Doi:10.1080/00221325.1967.10533749.

Loewenstein, G. (1994). The psychology of curiosity: A review and reinterpretation. Psychological Bulletin, 116(1), 75. 
Lowry, N., and Johnson, D. W. (1981). Effects of controversy on epistemic curiosity, achievement, and attitudes. The Journal of Social Psychology, 115(1), 3143. Doi:10.1080/00224545.1981.9711985.

Malone, T. W. (1981). Toward a theory of intrinsically motivating instruction. Cognitive science, 5(4), 333-369. Doi: 10.1016/S0364-0213(81)80017-1

McLeod, J. K. (2011). Digitally curious: A qualitative case study of students' demonstrations of curiosity in a technology-rich learning environment. Doctoral dissertation. University of North Texas.

Metcalfe, J., Schwartz, B. L. and Bloom, P. A. (2017). The tip-of-the-tongue state and curiosity. Cognitive Research: Principles and Implications, 2(1), 31. Doi: 10.1186/s41235017-0065-4.

Mussel, P. (2010). Epistemic curiosity and related constructs: Lacking evidence of discriminant validity. Personality and Individual Differences, 49(5), 506-510.

Palmatier, R.W., Houston, M.B. \& Hulland, J. (2018). Review articles: Purpose, process, and structure. J. of the Acad. Mark. Sci. 46, 1-5. https://doi.org/10.1007/s11747-017-0563-4

Piper, K. C. (2011). The knowledge of others: Cosmopolitanism and modern curiosity. Doctoral dissertation, University of Wisconsin-Madison. ProQuest veri tabanından erişilmiştir.

Powell, C., and Nettelbeck, T. (2014). Intellectual curiosity may not incrementally predict academic success. Personality and Individual Differences, 64, 7-11. Doi: 10.1016/j.paid.2014.01.045.

Reiro Jr, T. G., Petrosko, J. M., Wiswell, A. K., and Thongsukmag, J. (2006). The measurement and conceptualization of curiosity. The Journal of Genetic Psychology, 167(2), 117-135.

Richards, J. B., Litman, J., and Roberts, D. H. (2013). Performance characteristics of measurement instruments of epistemic curiosity in third-year medical students. Medical Science Educator, 23(3), 355-363.

Rinkevich, J. L. (2014). The relationship among student creativity, curiosity, and academic intrinsic motivation: A mixed methods phenomenological study of sixth grade students. Doctoral dissertation, Indiana University of Pennsylvania. ProQuest veri tabanından erişilmiştir.

Ross, M. (1975). Salience of reward and intrinsic motivation. Journal of Personality and Social Psychology, 32, 245-254.

Sarışan-Tungaç, A., Bal-İncebacak, B. ve Yaman, S. (2019).Ortaokullardaki yaratıcı drama etkinliklerinin Fen merak duygusuna etkisi. Amasya Üniversitesi Ĕgitim Fakültesi Dergisi, $8(1), 162-184$.

Schneider, A., Von Krogh, G., and Jäger, P. (2013). "What's coming next?" epistemic curiosity and lurking behavior in online communities. Computers in Human Behavior, 29(1), 293-303.

Seferoğlu, S. S., ve Akbıyık, C. (2006). Eleştirel düşünme ve öğretimi. Hacettepe Üniversitesi Eğitim Fakültesi Dergisi, 30(30), 193-200.

Slater, C. W. (2009). The measurement of an adult's cognitive curiosity and exploratory behavior. Doctorial Dissertation. Regent University. 
Smith, K. H. (2010). Curiosity and pedagogy: A mixed-methods study of student experiences in the design studio. Doctorial Dissertation. University of Arkansas, USA.

Sönmez, V. (2011). Öğretim ilke ve yöntemleri (6. Bask1). Ankara: Anı.

Spielberger, C. D. (Ed.). (1966). Anxiety and behavior. Academic Press.(e-book). https://books.google.com.tr veri tabanından erişilmiştir.

Spielberger, C. D., Peters, R. A. and Frain, F. (1981). Curiosity and anxiety. In H. G. Voss and H. Keller (Eds.), Curiosity research: Basic concepts and results. Weinheim: Beltz.

Taşkın, Ç. (2016). Öğretim stratejileri. G. Ekici (ed), Öğrenme-Öğretme Kuramları ve Uygulamadaki Yansımaları. Ankara: Pegem.

Tutkun, Ö. F. (2012). Bloom'un yenilenmiş taksonomisi üzerine genel bir bakış. Sakarya University Journal of Education, 1(3), 14-22.

Von Stumm, S., Hell, B., and Chamorro-Premuzic, T. (2011). The hungry mind: Intellectual curiosity is the third pillar of academic performance. Perspectives on Psychological Science, 6(6), 574588.

Y1ldızlar, M. (2011). Öğretim ilke ve yöntemleri (2.Bask1). Ankara: Pegem A.

Zion, M. I., and Sadeh, I. (2007). Curiosity and open inquiry learning. Journal of Biological Education, 41(4), 162-169. Doi: 10.1080/00219266.2007.9656092. 


\section{Extended Abstract}

\section{Introduction}

The orientation of the learner towards a specific information, concept or phenomenon in the learning process is an important issue in terms of the quality of the learning process. In this regard, why the learner attempts to learn a certain concept becomes the subject of investigation in terms of social / educational sciences. Learning realizes the change in the inner capacity of the learner. The learner prepares himself for the next learning experiences through affective factors such as motivation, interest and curiosity. The learner distinguishes the stimulus that draws his/her attention through his/her senses. Curiosity enables the learner to discover depending on cognitive and affective factors. It triggers the wish and desire of the learner to learn, and also controls the functioning of the learner's cognitive activities.

\section{A Conceptual Analysis for Curiosity}

Curiosity explanations show that curiosity is a deeper concept than willingness. When analyzed for philosophers, there are different approaches to the concept of curiosity. These are universiality, appetite, passion or a sense of satisfaction, physicality and willingness. It is also understood that curiosity was expressed as "greed to the degree of being insatiable with knowledge" until the 1950s.

\section{Curiosity Theories}

Curiosity which complexly connected to the learning process, generally, is the willingness to seek information. Curiosity is examined in different structures as a combination of multiple structures such as impulsive, motivational and cognitive-affective-motivational. Curiosity, according to drive theories, is an uncertain, disturbing situation caused by unknown stimuli. Curiosity in terms of psychoanalytic theory is the state of motivation to learn as a result of basic and intense drives.

According to the optimal level theorists, in terms of motivational conditions, curiosity occurs when there is a lack of curiosity. It is described as curiosity that the learner provides motivation to search for stimuli to continue the level of arousal. According to the Dual Process theory, while the learner provides motivation to encourage discovery behavior on the one hand, motivation is provided to reduce the learner's level of arousal in an emotional state such as anxiety (Fulcher, 2004). When examined in terms of state-trait theory, the state curiosity expresses the curiosity of the learner for a specific situation and condition. Trait curiosity is the capacity or predisposition of the learner to experience curiosity. In terms of contemporary learning approach, curiosity is based on the learner's research and discovery. For this reason, curiosity is examined in many ways in terms of motivation and stimuli, and is explained with the dimensions of physiological, social and intellectual curiosity.

Curiosity is explained in a cognitive motivational context by theories such as information gap. According to the information gap theory, curiosity occurs as a result of the mismatch in the perception process associated with the information gaps in the mind. Therefore, curiosity has been explained as a combination of two different structures, sensory-cognitive curiosity, specific-diversive curiosity, and perceptual-epistemic curiosity.

Affective curiosity includes the excitement and anxiety of the learner to discover objects. It is about how remarkable the stimuli in the environment are. For the learner, cognitive curiosity causes comprehension. As a result of understanding the knowledge, it causes the learner to experience the feeling of pleasure. It also makes the learner sensitive to information gaps. Specific curiosity aims to analyze the answers of unknown questions in depth in order to increase the knowledge and experience of a learner. The diversive curiosity increases stimulation by investigating new and difficult stimuli for the learner and reduces the inner restlessness of the learner (Ladd, 2018). Perceptual curiosity 
encourages the learner to exploration behavior to learn by stimuli. Epistemic curiosity occurs as a result of the inner conflict of the learner.

\section{Epistemic Curiosity}

Epistemic curiosity is explained by the sub-dimensions of interest and deprivation. The type of interest epistemic curiosity occurs when the learner has learning opportunities. For this reason, the learner takes into account the purpose of having fun, determines his/her own learning objectives, identifies self-control strategies and takes risks. Deprivation epistemic curiosity is about the integrity of the perception structure in the learner's mind. Deprivation-type epistemic curiosity is the lack of space between the structures in the mind or the leraner's search for information due to the meaninglessness caused by new information.

\section{The Role of Epistemic Curiosity in the Learning and Teaching Process}

The learning process is shaped with a learner centered depending on the contemporary education. For this reason, it has become necessary to examine the educational activities that support the learning orientation displayed by the learner in terms of epistemic curiosity. In the studies conducted, epistemic curiosity is related to the learning intent of the learner (Koo and Choi, 2010), learning goals (Litman 2008; 2012) and academic achievement (Ceylan, Sagirekmekçi, Tatar and Bilgin, 2016; Elmali Özsaray, 2016; Powell and Nettelbeck, 2014). For this reason, it is becoming an issue to examine how epistemic curiosity can affect the consistency of the goals set in teaching with structure, quality and students' intent. In studies on teaching strategies, it has been concluded that the research strategy increases the curiosity of the learner (Taskin, 2016; Zion and Sadeh 2007). This suggests that teaching strategies may be important for the development of epistemic curiosity. It is important to organize learning environments and processes to stimulate learners' senses to seek information. Especially in the process of solving a problem, exhibiting thinking and problem solving behavior takes place with epistemic curiosity (Cyr, 1996). In this process, epistemic curiosity provides motivation to seek information.

As a result, it is understood that epistemic curiosity is related to human cognitive structure and personality factors as well as learning and teaching process in many aspects. Also, it is understood that epistemic curiosity plays a mediator role with the variables related to the learning process and has become a structure that covers the learning-teaching process. It is suggested that the variables that mediate the role of epistemic curiosity in the learning process can be questioned through the researches to be conducted. 